\title{
Opposing roles for mammary epithelial-specific PPARy signaling and activation during breast tumour progression
}

Anthony J Apostoli', Jennifer M Roche', Mark M Schneider', Sandip K SenGupta', Michael A Di Lena', Rachel E Rubino ${ }^{2}$, Nichole T Peterson ${ }^{2}$ and Christopher JB Nicol ${ }^{1,2,3^{*}}$

\begin{abstract}
Background: Among women worldwide, breast cancer is the most commonly diagnosed cancer, and the second leading cause of cancer-related deaths. Improved understanding of breast tumourigenesis may facilitate the development of more effective therapies. Peroxisome proliferator-activated receptor (PPAR) $y$ is a transcription factor that regulates genes involved in insulin sensitivity and adipogenesis. Previously, we showed, using 7,12-dimethylbenz [a] anthracene (DMBA)-treated haploinsufficient PPARy mice, that PPARY suppresses breast tumour progression; however, the PPARY expressing cell types and mechanisms involved remain to be clarified. Here, the role of PPARY expression and activation in mammary epithelial cells (MG) with respect to DMBA-mediated breast tumourigenesis was investigated.
\end{abstract}

Methods: PPARY MG knockout (PPARY-MG KO) mice and their congenic, wild-type controls (PPARY-WT) were treated once a week for six weeks by oral gavage with $1 \mathrm{mg}$ DMBA dissolved in corn oil and maintained on a normal chow diet. At week 7, mice were randomly divided into those maintained on a normal chow diet (DMBA Only; PPARY-WT: $n=25$ and PPARY-MG KO: $n=39$ ) or those receiving a diet supplemented with the PPARy ligand, rosiglitazone (ROSI, $4 \mathrm{mg} / \mathrm{kg} /$ day) (DMBA + ROSI; PPARY-WT: $\mathrm{n}=34$ and PPARY-MG KO: $\mathrm{n}=17$ ) for the duration of the 25-week study.

Results: Compared to DMBA Only-treated PPARY-WTs, both breast tumour susceptibility and serum levels of proinflammatory and chemotactic cytokines, namely IL-4, eotaxin, GM-CSF, IFN- $\gamma$, and MIP-1a, were decreased among PPARY-MG KOs. Cotreatment with ROSI significantly reduced breast tumour progression among PPARY-WTs, correlating with increased BRCA1 and decreased VEGF and COX-2 protein expression levels in breast tumours; whereas, surprisingly DMBA + ROSI-treated PPARY-MG KOs showed increased breast tumourigenesis, correlating with activation of COX-2.

Conclusion: These novel data suggest MG-specific PPARy expression and signaling is critical during breast tumourigenesis, and may serve as a strong candidate predictive biomarker for response of breast cancer patients to the use of therapeutic strategies that include PPARy ligands.

Keywords: Breast cancer, PPARY, Mammary epithelial cells, Knockout mouse model, Chemotherapy

\footnotetext{
*Correspondence: nicolc@queensu.ca

'Department of Pathology and Molecular Medicine, Queen's University,

Kingston, ON, Canada

2Division of Cancer Biology and Genetics, Queen's Cancer Research Institute

(QCRI), Kingston, ON, Canada

Full list of author information is available at the end of the article
}

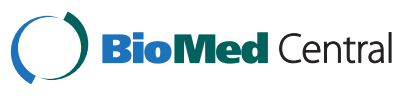

(c) 2015 Apostoli et al.; licensee BioMed Central. This is an Open Access article distributed under the terms of the Creative Commons Attribution License (http://creativecommons.org/licenses/by/4.0), which permits unrestricted use, distribution, and reproduction in any medium, provided the original work is properly credited. The Creative Commons Public Domain Dedication waiver (http://creativecommons.org/publicdomain/zero/1.0/) applies to the data made available in this article, unless otherwise stated. 


\section{Introduction}

Breast cancer is the most commonly diagnosed form of cancer among women worldwide with 1.7 million new cases identified and over 500,000 breast cancer-related deaths in 2012 [1]. Despite advances in early detection and treatment for many types of breast tumours, it remains difficult to predict which patients will suffer from aggressive forms of disease or respond poorly to current therapies. More work is needed to identify biomarkers that may reduce the number of deaths and improve quality of life for patients diagnosed with breast cancer.

Peroxisome proliferator-activated receptor (PPAR) $\gamma$ is a transcription factor that is primarily expressed in adipocytes [2], as well as mammary epithelial (MG) cells [3], and a majority of human breast tumour cell lines $[4,5]$. It regulates the expression of genes involved in glucose and lipid metabolism, with an emerging role in breast tumourigenesis [6]. The mechanisms by which PPAR $\gamma$ regulates gene expression are best reviewed elsewhere [7]. Ligands for PPARY include synthetic drugs from the thiazolidinedione (TZD) class [8]. Rosiglitazone (ROSI), a TZD family member, is a potent activator of PPAR $\gamma$ and prescribed to successfully treat some patients with Type II diabetes [9].

A breast tumour suppressor role for PPARy was first demonstrated in vitro when treatment of human MCF-7 and MDA-MB-231 breast cancer cells with PPAR ligands resulted in decreased cell proliferation, promotion of differentiation, and induction of apoptosis $[4,5,10,11]$. We provided the first direct in vivo evidence that PPAR $\gamma$ normally stops the growth and spread of breast and other tumour progression in a 7,12-dimethylbenz[a] anthracene (DMBA)-treated haploinsufficient $\mathrm{PPAR}^{(+/)}$mouse model [12]. To better define the mammary cell-specific importance of PPAR $\gamma$ during breast tumourigenesis, we more recently showed that in vivo expression and activation of PPAR $\gamma$ in both virgin mammary stromal adipocytes and post-lactational secretory epithelial cells protects against DMBA-induced breast tumourigenesis $[13,14]$. Here we sought to explore the role of virgin mammary epithelial cell (MG)-specific PPARY signaling and activation during DMBA-mediated breast tumourigenesis using conditional PPAR $\gamma$-MG KO mice. It was hypothesized that MG-specific PPARy expression is protective during breast tumourigenesis, and that this effect could be amplified via ROSI activation of PPARY in MG cells. Here we unveil evidence that MG-specific PPAR $\gamma$ expression enhances early breast tumour events; whereas, more importantly activation of MG-specific PPAR $\gamma$ dependent signaling reduces breast tumour progression.

\section{Results}

Based on observations in our lab and previous reports [15], PPAR $\gamma$-WT and PPAR $\gamma$-MG KO mice are not prone to spontaneous tumour formation, suggesting any tumours that arose were a result of DMBA initiation. In regards to tumourigenic response, overall survival (OS) for PPAR $\gamma$-WT and PPAR $\gamma$-MG KO mice are shown in Figure $1 \mathrm{~A}$ and $\mathrm{B}$ respectively, and for DMBA Only-treated and DMBA + ROSI-treated mice are shown in Figure $1 \mathrm{C}$ and $\mathrm{D}$ respectively. Within genotypes, DMBA + ROSI-treated PPAR $\gamma$-WTs had a significantly improved OS compared to their respective DMBA Onlytreated controls (respective median OS: 21.5 vs. 17 weeks, $\mathrm{p}$ < 0.05). Interestingly, among PPAR $\gamma-\mathrm{MG} \mathrm{KO}$ mice, cotreatment significantly worsened OS outcomes compared to DMBA Only-treated controls (respective median OS: 21 weeks vs. undefined, $\mathrm{p}<0.05)$. Among DMBA Only-treated groups, PPAR $\gamma$-MG KO mice showed a strong statistically significant advantage in OS compared to PPAR $\gamma$-WTs $(\mathrm{p}<0.0001)$; however, this difference was not retained between DMBA + ROSItreated genotypes.

Tumours were differentially observed in tissues among all groups, and were consistent with the pattern of DMBA-initiated tumourigenesis (Table 1). In the DMBA Only-treated group, PPAR $\gamma$-WT mice had a total tumour incidence of $80 \pm 8 \%$ compared to $67 \pm 8 \%$ for PPAR $\gamma$-MG KOs (Figure 1E). In the DMBA + ROSI group, total tumour incidence was similar for PPAR $\gamma$ WTs $(76 \pm 7 \%)$ and PPAR $\gamma$-MG KO $(76 \pm 10 \%)$ mice. In DMBA Only-treated mice, mammary tumour incidences were modestly higher among PPAR $\gamma$-WTs $(32 \pm$ 9\%) compared to PPAR $\gamma$-MG KOs $(26 \pm 7 \%)$. In contrast, between DMBA + ROSI-treated strains, PPAR $\gamma$ MG KO mice had a $\sim 2$-fold higher mammary tumour incidence compared to PPAR $\gamma$-WTs $(53 \pm 12$ vs. $29 \pm 8 \%$, respectively), although this trend was not statistically significant. Further, DMBA + ROSI-treated PPAR $\gamma$-MG KO mice exhibited a $\sim 2$-fold higher incidence of mammary tumours compared to DMBA Only-treated PPAR $\gamma$-MG KOs $(53 \pm 12 \%$ vs. $26 \pm 7 \%$, respectively) in a trend that approached statistical significance $(\mathrm{p}=0.07)$.

In DMBA Only-treated mice, PPAR $\gamma$-MG KOs also had a significant $\sim 3.5$-fold reduction in liver tumour incidence compared to PPAR $\gamma$-WTs $(13 \pm 5 \%$ vs. $48 \pm$ $10 \%$, respectively; $\mathrm{p}<0.01)$. Cotreatment with DMBA + ROSI halved liver tumour incidences in both genotypes, although these changes were not significantly different. Furthermore, PPAR $\gamma$-MG KOs had a significant $\sim 4$-fold decrease in thymic tumour incidence compared to PPAR $\gamma$-WT mice in the DMBA Only-treated group (10 $\pm 5 \%$ vs. $40 \pm 10 \%$, respectively; $\mathrm{p}<0.05$ ). Among cotreated groups, thymic tumour incidences were not different between genotypes but did significantly decrease by $\sim 3$-fold among PPAR $\gamma$ WT mice compared to their respective DMBA Onlytreated PPAR $\gamma$-WT controls $(\mathrm{p}<0.05)$. 

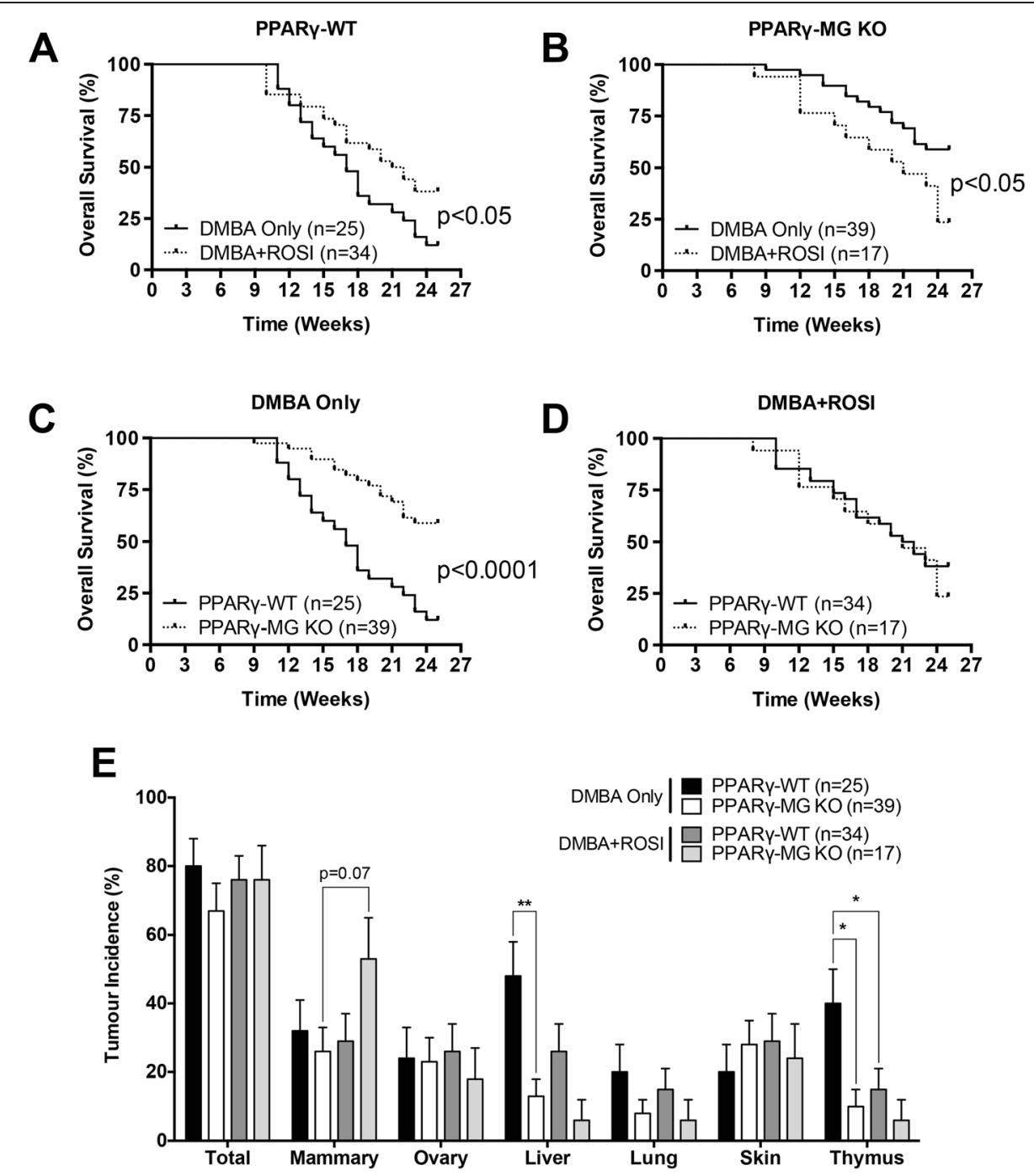

Figure 1 In vivo effects of MG-specific PPARy loss on survival and total tumour outcomes. Overall survival outcomes for (A) PPARY-WT and (B) PPARY-MG KO mice are shown. Solid lines, DMBA Only treatment; broken lines, DMBA + ROSI treatment. Overall survival for (C) DMBA Only- and (D) DMBA + ROSI-treated mice are shown. Solid lines, PPARY-WTs; broken lines, PPARY-MG KOs. (E) Tumour incidences are shown for each strain across each treatment group for total, mammary, ovarian, liver, lung, skin and thymic tumours. ${ }^{*}, p<0.05 ;{ }^{* *}, p<0.01$.

When mammary tumours were analyzed by pathological stage (Figure 2A), DMBA Only-treated PPAR $\gamma$-MG KO mice exhibited a reduction in malignant mammary tumours versus PPAR $\gamma$-WTs ( $5 \pm 4 \%$ vs. $20 \pm 8 \%$, respectively; not significant). DMBA + ROSI cotreatment did not significantly change PPAR $\gamma$-WT malignant mammary tumour incidence, but intriguingly, significantly increased malignant mammary tumour incidence by $\sim 8$-fold in PPAR $\gamma$-MG KO mice $(\mathrm{p}<0.01)$. For either genotype treated with DMBA only versus DMBA + ROSI, the incidences of benign mammary tumours were non-significantly reduced in PPAR $\gamma$ WTs $(16 \pm 7 \%$ vs. $12 \pm 6 \%$ respectively) and PPAR $\gamma$-MG KOs ( $23 \pm 7 \%$ vs. $18 \pm 9 \%$, respectively).

Mammary tumours were measured (length and width) to monitor volumes as soon as they became palpable
(Figure 2B) [16]. DMBA Only-treated PPAR $\gamma$-MG KO mice had a significant $\sim 5$-fold decrease in mean mammary tumour volume compared to similarly treated PPAR $\gamma$-WTs (mean log volume: $360.6 \mathrm{~mm}^{3}$ vs. $1843 \mathrm{~mm}^{3}$, respectively; $\mathrm{p}<0.05)$. Cotreatment with DMBA + ROSI abolished this genotypic difference, and resulted in similar mean mammary tumour volumes via increases in PPAR $\gamma$ WTs $\left(806.9 \mathrm{~mm}^{3}\right)$ and decreases in PPAR $\gamma$-MG KOs $\left(818.0 \mathrm{~mm}^{3}\right)$. The effects of treatment on mammary tumour volumes within each genotype were not statistically significant.

Among PPAR $\gamma$-WT mice, palpable mammary tumours were first observed following DMBA treatment at week 11 , and at week 13 in the DMBA + ROSI-treated group (Figure 2C). With respect to mammary tumour latency, 
Table 1 DMBA-induced tumours in PPARY-WT and PPARY-MG KO mice

\begin{tabular}{|c|c|c|c|c|}
\hline & \multicolumn{2}{|c|}{ DMBA Only-treated mice } & \multicolumn{2}{|c|}{ DMBA + ROSI-treated mice } \\
\hline & PPAR $\gamma-W T(n=25)$ & PPAR $\gamma$-MG KO $(n=39)$ & PPAR $\gamma-W T(n=34)$ & PPARY-MG KO $(n=17)$ \\
\hline Mammary tumour type & \multicolumn{4}{|c|}{ Tumours/Mouse (\# Tumours) } \\
\hline Benign tumour & $0.20(5)$ & $0.26(10)$ & $0.15(5)$ & $0.18(3)$ \\
\hline Squamous cyst & $0.12(3)$ & $0.08(3)$ & $0.09(3)$ & $0.06(1)$ \\
\hline Spindle tumour & $0.04(1)$ & - & - & - \\
\hline Adenoma & $0.04(1)$ & - & $0.06(2)$ & - \\
\hline Lipoma & - & $0.03(1)$ & - & - \\
\hline Other & - & $0.15(6)$ & - & $0.12(2)$ \\
\hline Squamous cell carcinoma & $0.08(2)$ & $0.03(1)$ & $0.26(9)$ & $0.29(5)$ \\
\hline Spindle cell carcinoma & $0.08(2)$ & - & - & - \\
\hline Adenocarcinoma & - & - & $0.12(4)$ & - \\
\hline Other carcinoma & $0.08(2)$ & $0.03(1)$ & - & $0.29(5)$ \\
\hline Total mammary tumours & $0.44(11)$ & $0.31(12)$ & $0.53(18)$ & $0.76(13)$ \\
\hline Benign mammary & $0.20(5)$ & $0.26(10)$ & $0.15(5)$ & $0.18(3)$ \\
\hline Malignant mammary & $0.24(6)$ & $0.05(2)$ & $0.38(13)$ & $0.59(10)$ \\
\hline Non-mammary tumour/tissue affected & \multicolumn{4}{|c|}{ Tumours/Mouse (\# Tumours) } \\
\hline Skin & $0.20(5)$ & $0.41(16)$ & $0.35(12)$ & $0.41(7)$ \\
\hline Ovarian/Uterine & $0.24(6)$ & $0.26(10)$ & $0.26(9)$ & $0.13(3)$ \\
\hline Thymus & $0.40(10)$ & $0.10(4)$ & $0.15(5)$ & $0.06(1)$ \\
\hline Spleen & $0.04(1)$ & $0.03(1)$ & - & - \\
\hline Liver & $0.48(12)$ & $0.13(5)$ & $0.26(9)$ & $0.06(1)$ \\
\hline Lung & $0.20(5)$ & $0.08(3)$ & $0.15(5)$ & $0.06(1)$ \\
\hline Gastrointestinal & $0.04(1)$ & $0.05(2)$ & $0.06(2)$ & $0.06(1)$ \\
\hline Lymphoma & - & $0.13(4)$ & $0.03(1)$ & - \\
\hline Total tumours & $2.04(51)$ & $1.46(57)$ & $1.79(61)$ & $1.59(27)$ \\
\hline Benign total & $0.64(16)$ & $0.82(32)$ & $0.74(25)$ & $1.06(18)$ \\
\hline Malignant total & $1.40(35)$ & $0.64(25)$ & $1.05(36)$ & $0.53(9)$ \\
\hline
\end{tabular}

The number of breast tumours per mouse (multiplicity) is indicated with the total number in parenthesis. Mammary tumours were also sub-stratified and expressed as multiplicity of benign, malignant, and metastatic tumours per genotype and treatment. Examples of benign mammary tumour subtypes are also indicated. For non-mammary tissue, the numbers of each tumour per mouse is also indicated with the total number in parenthesis. Finally, total tumours were sub-stratified and expressed as the multiplicity of benign, malignant, and metastatic tumours per genotype and treatment.

25\% of DMBA Only-treated PPAR $\gamma$-WTs developed palpable tumours by week 15 , whereas this trended toward week 21.5 in DMBA + ROSI-treated PPAR $\gamma-W T$ mice. Interestingly, DMBA Only-treated PPAR $\gamma-M G$ KOs first developed palpable tumours by week 13, in comparison to DMBA + ROSI-treated PPAR $\gamma$-MG KOs in which palpable tumours were noted as early as week 10. Twenty-five percent of DMBA Only-treated PPAR $\gamma$ MG KO mice developed palpable mammary tumours by week 25, and this significantly declined to week 16 in DMBA + ROSI-treated PPAR $\gamma-M G$ KOs $(\mathrm{p}<0.01)$. Similarly, DMBA + ROSI-treated PPAR $\gamma-M G$ KOs showed a significant decrease in mammary tumour latency compared to similarly treated PPAR $\gamma$-WT mice (with $25 \%$ of mice developing palpable mammary tumours at week 16 vs. 21.5 , respectively; $\mathrm{p}<0.05$ ).
Representative sections of normal mammary tissue and mammary tumours from PPAR $\gamma-W T$ and PPAR $\gamma$ MG KO mice in each treatment group were hematoxylin and eosin (H\&E) stained and examined in a blinded fashion by collaborating pathologists for changes in morphological characteristics. Untreated mammary glands collected at week 12 from either strain were not morphologically different from one another and exhibited characteristic features of normally developed mammary glands (Figure 3A and B). Both were comprised primarily of adipocytes, as expected in the mouse mammary gland. Tumours taken from PPAR $\gamma$-WT mice treated with DMBA Only were primarily classified as malignant carcinomas with mixed squamous differentiation (Figure 3C). DMBA Only-treated PPAR $\gamma$-MG KO mammary tumours showed comparatively more benign characteristics (Figure 3D). In 


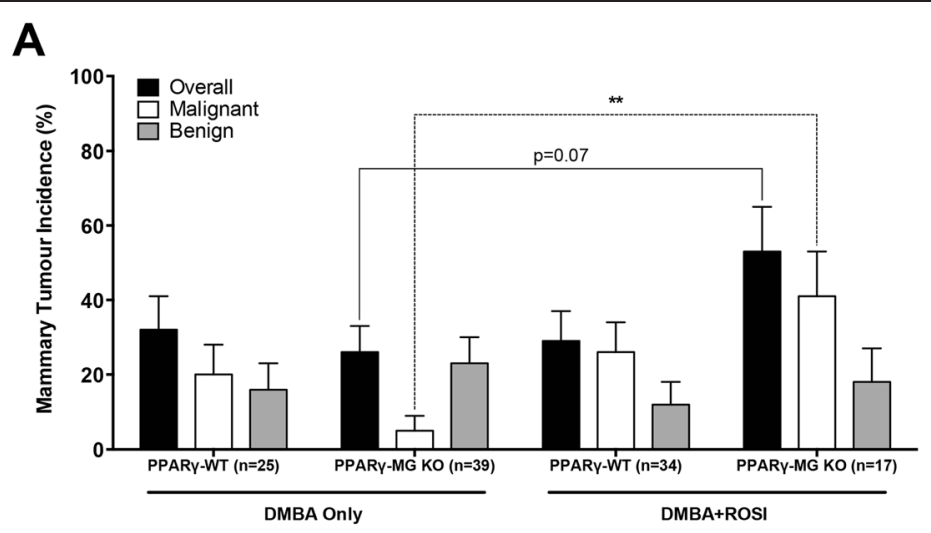

B
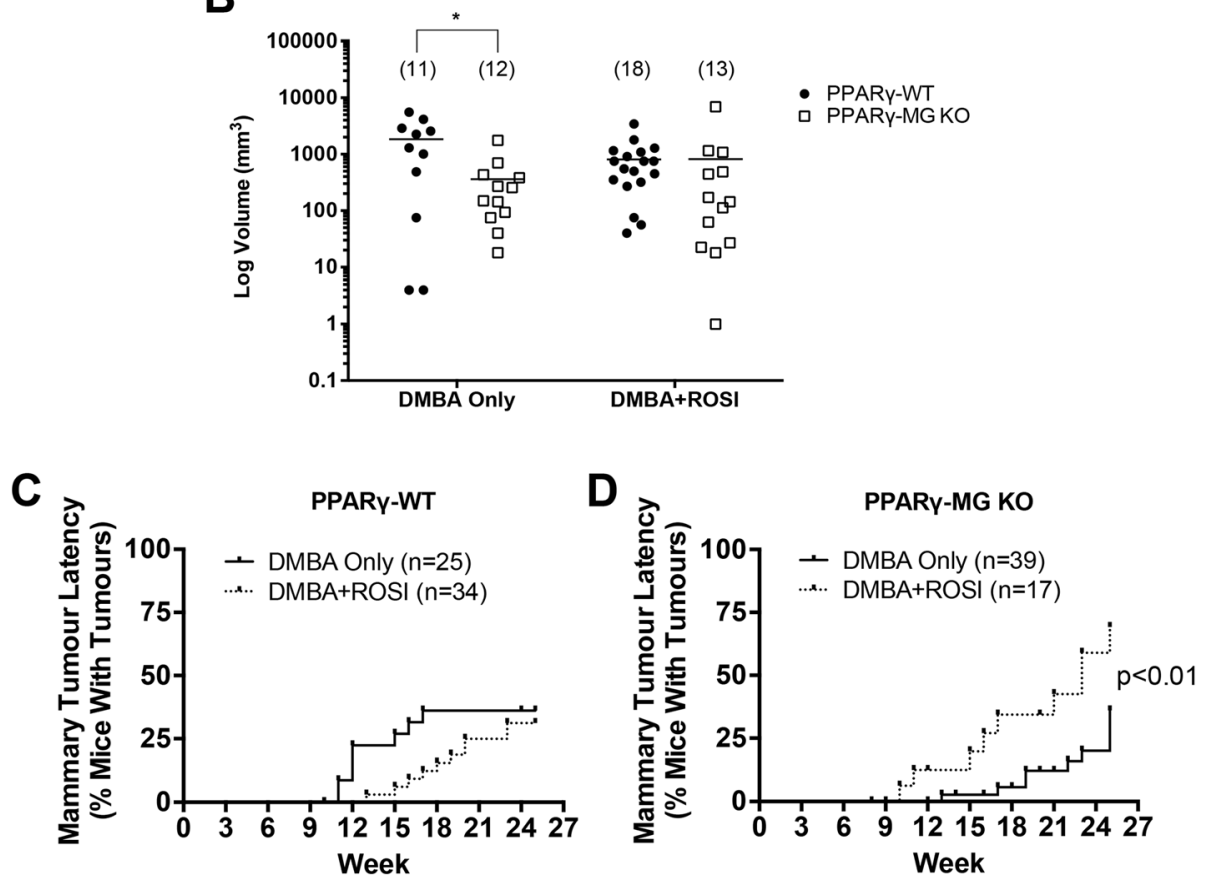

Figure 2 In vivo effects of MG-specific PPARy deletion on mammary tumour incidence, tumour volume and latency. (A) Mammary tumour incidences, as well as incidences of benign and malignant mammary tumours, are shown for each strain across each treatment group. ${ }^{* *}$, $p<0.01$. (B) Mammary tumour volumes were calculated using the standard formula $\left(L \times W^{2} / 2\right)$ and are expressed as $\mathrm{mm}^{3}$ on a log scale. Solid lines, mean tumour volume for each strain; solid circles, PPARY-WTs; open squares, PPARY-MG KOs; ${ }^{*}, \mathrm{p}<0.05$. Mammary tumour latency is expressed as the percentage of palpable mammary tumours within (C) PPARY-WT and (D) PPARY-MG KO strains in a given week. Solid lines, DMBA Only treatment; broken lines, DMBA + ROSI treatment.

DMBA + ROSI-treated mice, mammary tumours isolated from PPAR $\gamma$-WT mice were primarily identified as squamous cell carcinomas (Figure $3 \mathrm{E}$ ); whereas, those from PPAR $\gamma$-MG KO mice were classified as more malignant lesions that ranged from well-to-moderately differentiated (Figure 3F).

To evaluate protein expression changes in situ, mean fluorescence intensities of target proteins were quantified in three regions within each analyzed mammary tumour (Figure 4A). BRCA1 was evaluated in this manner because it is a known tumour suppressor gene, whose gene promoter contains a PPRE [17]. Mammary glands from untreated strains, included for reference (Additional file 1: Figure S1), illustrate decreased PPAR $\gamma$ and BRCA1 expression in cytokeratin-positive MG cells in PPAR $\gamma-M G K O$ mice compared to PPAR $\gamma$-WTs. Results show no differences in both PPAR $\gamma$ and BRCA1 among mammary-derived tumours from DMBA-treated PPAR $\gamma-M G K O$ and PPAR $\gamma$-WT mice (PPAR $\gamma$ : $1822 \pm$ 999 vs. $1459 \pm 377$, respectively and BRCA1: $1007 \pm 432$ vs. $1280 \pm 258$, respectively) (Figure 4B). Compared to DMBA Only-treated controls, irrespective of genotype, mammary tumours from mice treated with DMBA + ROSI trended toward increased PPAR $\gamma$ expression accompanied 


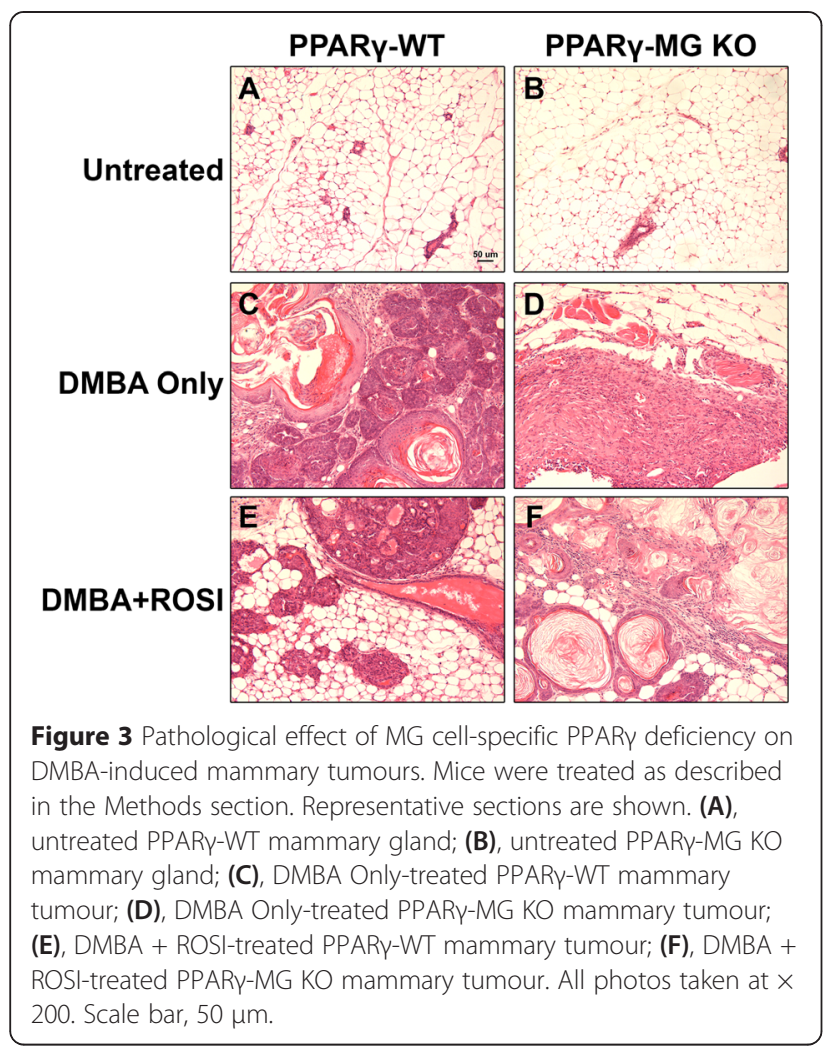

by increased BRCA1 expression $(\mathrm{p}=0.09)$. Importantly, DMBA + ROSI treatment significantly increased BRCA1 expression $\sim 3.5$-fold in PPAR $\gamma$-WT mice compared to both DMBA Only-treated PPAR $\gamma$-WTs $(4400 \pm 915$ vs. $1280 \pm 258$, respectively; $\mathrm{p}<0.01$ ), and DMBA + ROSItreated PPAR $\gamma$-MG KOs $(1707 \pm 180 ; \mathrm{p}<0.01)$.

Protein expression changes were determined by immunoblotting in mammary tumours from DMBA Only- and DMBA + ROSI-treated strains (Figure 5A). Untreated mammary tissues from PPAR $\gamma$-WT and PPAR $\gamma$ MG KO mice illustrate PPAR $\gamma$ is reduced in the latter and are representative of results from multiple independent experiments. Densitometric analyses of protein expression within mammary tumours revealed surprisingly similar PPARY protein levels irrespective of genotype or treatment (Figure 5B). Intriguingly, DMBA + ROSI-treated PPAR $\gamma$-MG KO mammary tumours exhibited a significant $\sim 4$-fold increase in Cox-2 compared to DMBA Only-treated PPAR $\gamma$-MG KOs ( $\mathrm{p}<$ 0.01 ), as well as a significant $\sim 3$-fold increase in Cox-2 compared to DMBA + ROSI-treated PPAR $\gamma$-WT mice $(\mathrm{p}<0.01)$. A significant $\sim 6$-fold reduction in PTEN was observed among DMBA Only-treated PPAR $\gamma$-MG KOs compared to similarly treated control mice $(\mathrm{p}<0.0001)$. No change in PTEN expression was observed among DMBA Only- and DMBA + ROSI-treated PPAR $\gamma$-MG KOs; however, it was interesting to note that ROSI cotreatment produced a significant $\sim 4$-fold reduction in
PTEN in PPAR $\gamma$-WT mice compared to DMBA Onlytreated controls $(\mathrm{p}<0.0001)$.

A 23-plex cytokine array was performed on serum samples from both PPAR $\gamma$-WT and PPAR $\gamma$-MG KO strains for untreated, DMBA Only-treated, and DMBA + ROSI-treated mice (Figure 6). Among untreated mice, there were significantly lower levels of GM-CSF ( 2.5fold; $\mathrm{p}<0.05)$ observed in PPAR $\gamma$-MG KOs compared to PPAR $\gamma$-WT mice (Table 2). DMBA + ROSI treatment significantly reduced serum GM-CSF ( 3.5-fold; $\mathrm{p}<$ 0.01 ), and non-significantly decreased serum eotaxin $(\sim 11$-fold; $\mathrm{p}<0.10)$, in PPAR $\gamma$-MG KO mice compared to similarly treated PPAR $\gamma$-WTs. Interestingly, PPAR $\gamma$ MG KOs showed significantly lower levels of serum IL-4 ( $<<0.01)$, IL-10 ( $<<0.001)$, IL-13 ( $<<0.05)$, eotaxin $(\mathrm{p}<0.01)$, GM-CSF $(\mathrm{p}<0.0001)$, IFN- $\gamma(\mathrm{p}<0.05)$ and MIP- $1 \alpha(\mathrm{p}<0.01)$, as well as a trend toward reduced levels of KC ( $\mathrm{p}=0.08)$, compared to PPAR $\gamma$-WTs.

Given their putative relevance to mammary tumour growth, serum VEGF, leptin and PGE metabolites were also quantified by separate ELISA experiments in both untreated strains and those treated with DMBA alone or DMBA + ROSI (Table 2). No significant differences were observed in serum leptin and PGE metabolite levels between genotypes or treatment groups. In contrast, DMBA Only-treated PPAR $\gamma$-MG KOs had significantly $\sim 3$-fold lower serum VEGF levels compared to similarly treated PPAR $\gamma$-WTs $(\mathrm{p}<0.05)$. VEGF expression was also significantly reduced $\sim 4$-fold in DMBA + ROSI compared to DMBA Only levels in PPAR $\gamma$-WTs $(\mathrm{p}<0.05)$, but not PPAR $\gamma$-MG KOs.

\section{Discussion}

Given recent evidence implicating a protective role for PPAR $\gamma$ in breast cancer $[12,13,14]$, the MG cellspecific contribution of this receptor was evaluated during DMBA-induced breast tumourigenesis using PPAR $\gamma-M G K O$ and PPAR $\gamma$-WT mice. Cotreatment with a gold standard PPAR $\gamma$ activator, ROSI, further provided the ability to identify PPAR $\gamma$-dependent antibreast tumour progression signaling pathways specific to MG cells. Other groups have examined the MGspecific contribution of PPAR $\gamma$ in breast cancer, using overexpression [18] and dominant negative knockout [19] approaches that only target the PPAR 1 isoform. Here, the Cre-loxP system was used to delete expression of both PPAR $\gamma$ protein isoforms, and thus, eliminate any confounding compensatory effects. In addition, the ROSI dose and regimen used here was previously shown to effectively activate PPAR $\gamma$ signaling [20-22] and achieve serum glucose profiles within human therapeutic ranges in mice [23,24]. Surprisingly, it was discovered that PPAR $\gamma$-MG KO mice are protected more so than PPAR $\gamma$-WTs during DMBA-mediated breast 

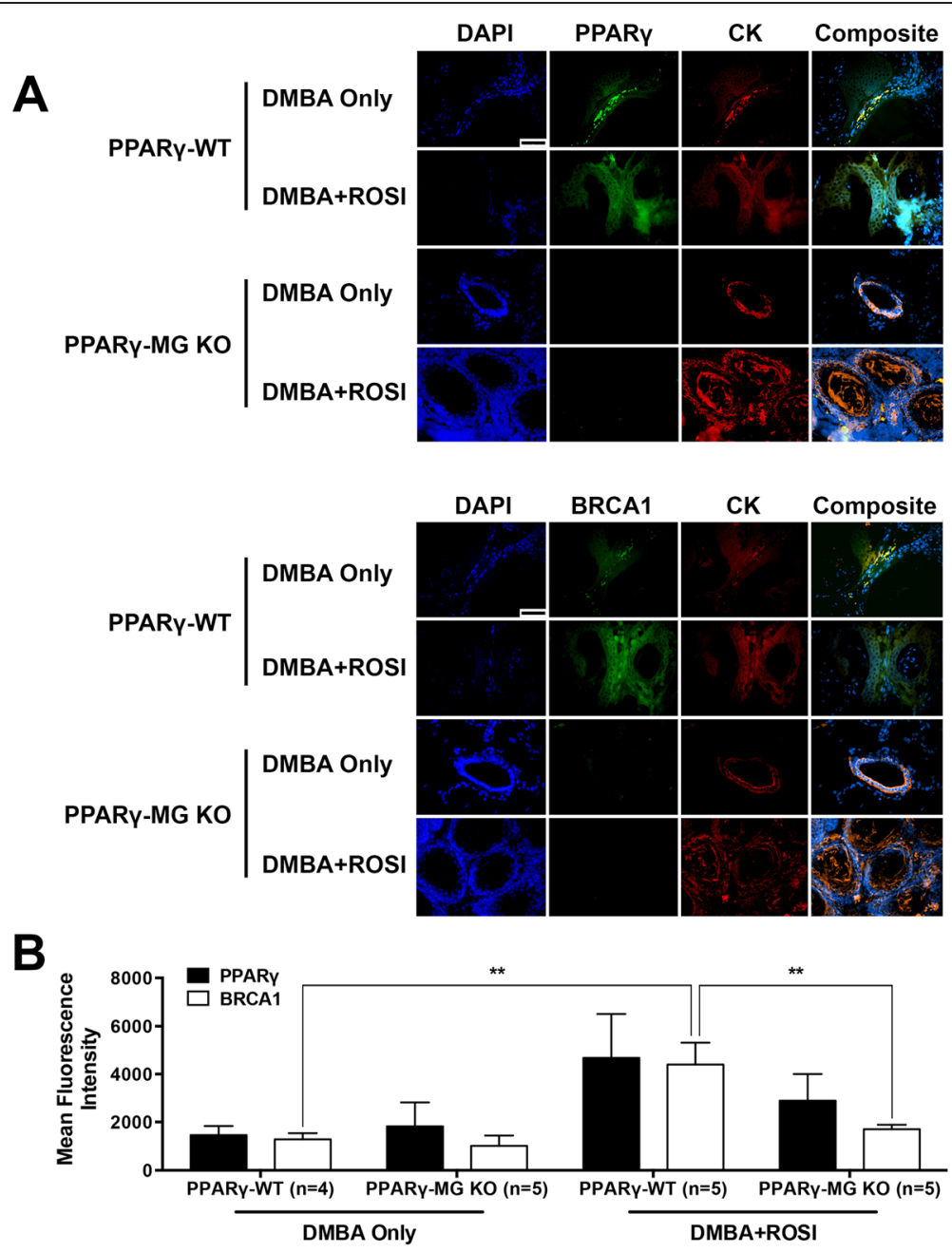

Figure 4 PPARY and BRCA1 expression in DMBA-mediated mammary-derived tumours. (A) Representative immunofluorescence images illustrating expression of cell nuclei (DAPl; in blue), PPARY or BRCA1 (in green) and cytokeratin (CK; in red), with an accompanying composite image, in mammary-derived tumours from PPARY-WT and PPARY-MG KO mice. All photos taken at $\times 600$. Scale bar, 50 um. (B) Quantification of global mean fluorescence intensity for PPARy or BRCA1 in tumours was performed using Image Pro Plus software. ${ }^{*}, p<0.01$.

tumourigenesis; whereas, PPAR $\gamma$ activation by ROSI rescues PPAR $\gamma$-WTs but renders PPAR $\gamma$-MG KOs more susceptible to breast tumour progression. These findings suggest that PPARY expression within MG cells may be a strong candidate biomarker for identifying patient populations with aggressive breast tumours, as well as aid in predicting patients likely to benefit from novel chemotherapeutic use of PPAR $\gamma$ activating drugs.

The findings that PPAR $\gamma-\mathrm{MG}$ KO mice respond more favourably, for example in OS, than PPAR $\gamma$-WTs following tumourigenic initiation by DMBA, but do worse following cotreatment with a PPAR $\gamma$ activating ligand were unexpected. These surprising outcomes may be explained, at least in part, by the increased total mammary tumour and malignant mammary tumour incidences, and decreased mammary tumour latency, that were observed in
DMBA + ROSI-treated PPAR $\gamma$-MG KOs compared to those treated with DMBA alone. Collectively, these findings suggest that PPAR $\gamma$ expression in MG cells and ROSI activation in mice lacking MG-specific PPAR $\gamma$ is potentially harmful during chemical-mediated breast tumour progression. Given that ROSI activation produced detrimental effects exclusive to knockout mice suggests that PPAR $\gamma$-independent effects of this drug may be partly responsible [25]. These interesting observations underscore the importance of personalized medicine, and the need for characterizing normal breast and mammary tumour epithelial expression of PPARY before considering TZDlike drugs as chemotherapeutic strategies for breast cancer patients. ROSI may still represent a viable chemotherapeutic option if expression of MG cell-specific PPAR $\gamma$ remains intact. 

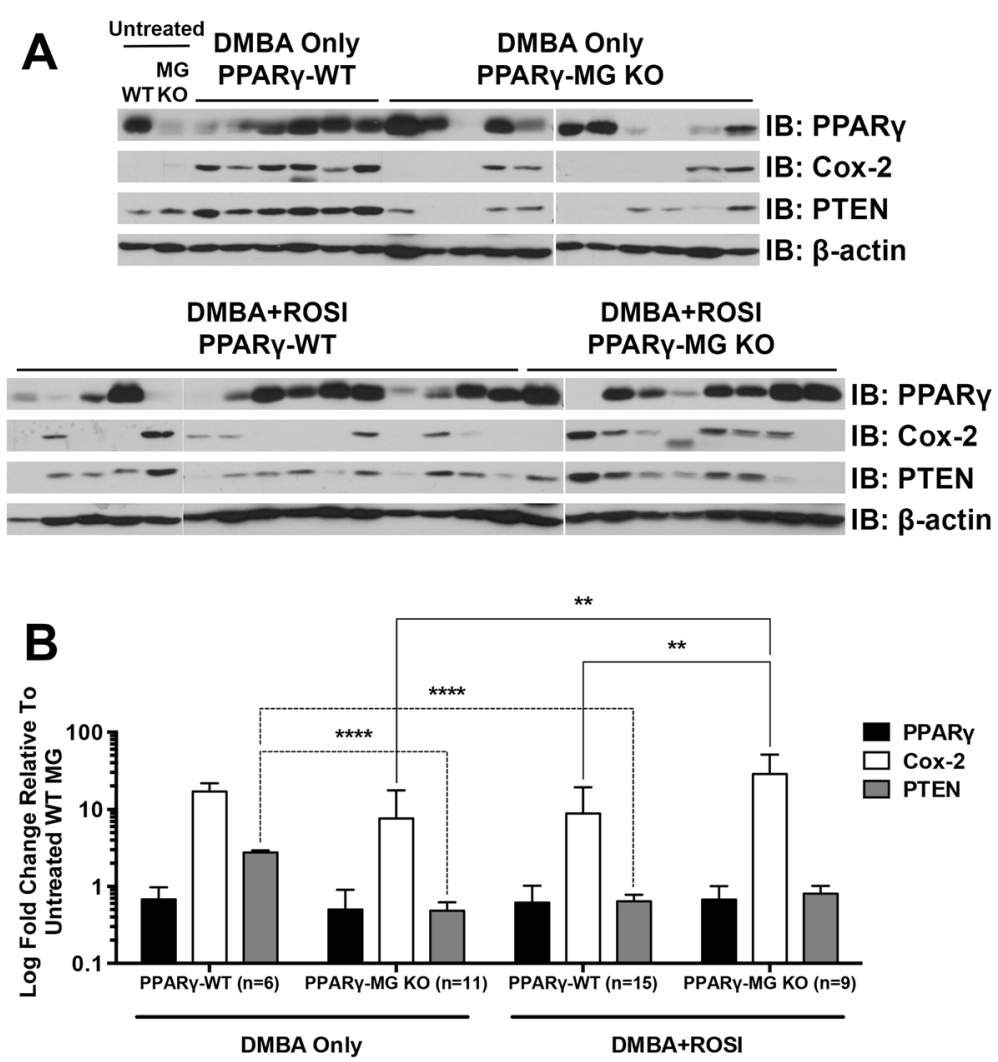

Figure 5 Molecular analysis from untreated mammary glands and DMBA-induced mammary tumours. (A) Representative protein expression changes within untreated mammary glands (MG) and in vivo generated mammary tumours in DMBA Only-and DMBA + ROSI-treated groups were analyzed by Western Blot as described in the Methods section. PPARY, Cox-2 and PTEN protein levels were analyzed in untreated virgin MG from PPARY-WT (WT) and PPARY-MG KO (MG KO) mice, as well as all available breast tumour subtypes from both strains of mice. $\beta$-actin served as loading control. (B) Densitometry for PPARY, Cox-2 and PTEN were performed on all mammary tumours using ImageJ software, and expressed as mean $\pm \mathrm{SD}$. Fold changes are relative to mammary tissue from untreated PPARY-WT. Black bars, PPARy expression; white bars, Cox-2 expression; grey bars, PTEN expression; **, $p<0.01$; $^{* * *}, \mathrm{p}<0.0001$.

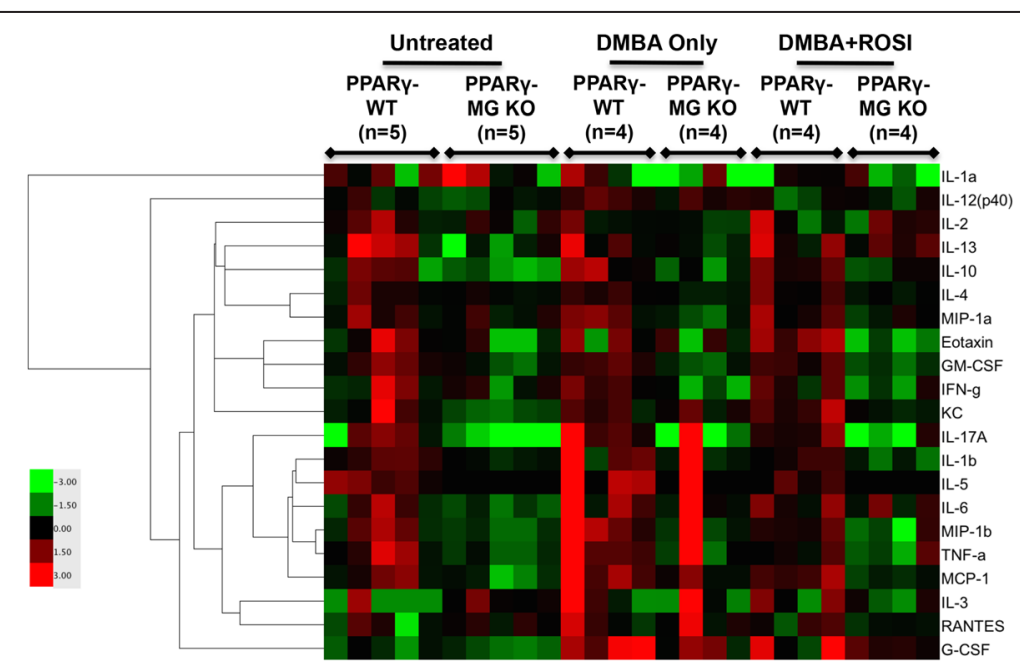

Figure 6 Heatmap reconstruction of 23-plex cytokine analyses resulting from MG-specific PPARY loss. A heatmap generated from a 23-plex cytokine array illustrating serum concentrations of cytokines from untreated, DMBA Only- and DMBA + ROSI-treated PPARY-WT and PPARY-MG KO strains. Mean cytokine concentrations $(\mathrm{pg} / \mathrm{ml})$ are visually represented on a log scale with red, black and green indicating high, median and low, respectively (refer to colour bar). IL-9 and IL-12(p70) were omitted from the table since values were below the level of detection. 
Table 2 Serum concentrations of cytokines from untreated, DMBA Only- and DMBA + ROSI-treated strains

\begin{tabular}{|c|c|c|c|c|c|c|}
\hline & \multicolumn{3}{|c|}{ PPARY-WT } & \multicolumn{3}{|c|}{ PPARY-MG KO } \\
\hline & $\begin{array}{l}\text { Untreated } \\
(n=5)\end{array}$ & $\begin{array}{l}\text { DMBA Only } \\
(n=4)\end{array}$ & $\begin{array}{l}\text { DMBA + ROSI } \\
(n=4)\end{array}$ & $\begin{array}{l}\text { Untreated } \\
(n=5)\end{array}$ & $\begin{array}{l}\text { DMBA Only } \\
(n=4)\end{array}$ & $\begin{array}{l}\text { DMBA + ROSI } \\
(n=4)\end{array}$ \\
\hline Cytokine [signif] & \multicolumn{6}{|c|}{ mean $\pm S D ;$ all values expressed as $\mathrm{pg} / \mathrm{ml}$} \\
\hline IL-1a & $90.6 \pm 56.6$ & $93.9 \pm 106.3$ & $48.9 \pm 32.9$ & $177.0 \pm 206.4$ & $39.8 \pm 66.1$ & $36.8 \pm 46.0$ \\
\hline IL-1 $\beta$ & $372.6 \pm 105.3$ & $3016.0 \pm 5279.0$ & $309.0 \pm 74.0$ & $195.4 \pm 25.9$ & $870.9 \pm 1383.0$ & $116.7 \pm 91.1$ \\
\hline IL-2 & $62.8 \pm 47.0$ & $42.4 \pm 27.9$ & $64.6 \pm 80.3$ & $34.9 \pm 15.0$ & $24.8 \pm 6.1$ & $41.8 \pm 32.9$ \\
\hline IL-3 & $6.8 \pm 15.2$ & $63.4 \pm 111.5$ & $16.0 \pm 13.6$ & $12.9 \pm 6.6$ & $25.4 \pm 40.9$ & $6.8 \pm 5.6$ \\
\hline IL-4 [gg] & $16.1 \pm 7.9$ & $16.4 \pm 3.2$ & $20.1 \pm 10.0$ & $11.8 \pm 1.5$ & $10.4 \pm 1.2$ & $11.0 \pm 1.1$ \\
\hline IL-5 & $40.0 \pm 16.3$ & $280.7 \pm 454.0$ & $23.2 \pm 17.2$ & ND & $77.4 \pm 154.8$ & $4.6 \pm 9.3$ \\
\hline IL-6 & $18.0 \pm 16.4$ & $215.5 \pm 387.5$ & $20.7 \pm 12.0$ & $5.7 \pm 1.5$ & $62.7 \pm 106.6$ & $14.5 \pm 8.5$ \\
\hline IL-9 & ND & ND & ND & ND & ND & ND \\
\hline IL-10 [ggg] & $97.3 \pm 64.6$ & $163.2 \pm 114.2$ & $117.6 \pm 48.8$ & $23.5 \pm 9.5$ & $39.7 \pm 19.9$ & $52.0 \pm 20.9$ \\
\hline IL-12(p40) [tt] & $694.9 \pm 299.5$ & $1212.0 \pm 302.4$ & $625.3 \pm 314.0$ & $554.5 \pm 176.1$ & $971.7 \pm 306.8$ & $665.1 \pm 227.3$ \\
\hline IL-12(p70) & ND & ND & ND & ND & ND & ND \\
\hline IL-13 $[g]$ & $654.1 \pm 638.6$ & $410.6 \pm 437.3$ & $440.6 \pm 380.4$ & $95.4 \pm 71.7$ & $124.9 \pm 33.2$ & $248.0 \pm 91.7$ \\
\hline IL-17A & $32.3 \pm 23.8$ & $588.5 \pm 1114.0$ & $34.9 \pm 19.5$ & $2.1 \pm 3.2$ & $150.3 \pm 294.5$ & $7.8 \pm 12.6$ \\
\hline Eotaxin [gg] & $1552.0 \pm 1593.0$ & $1141.0 \pm 890.4$ & $2016.0 \pm 743.7$ & $400.4 \pm 397.5$ & $620.8 \pm 482.6$ & $188.4 \pm 163.4$ \\
\hline G-CSF & $199.6 \pm 85.9$ & $1631.0 \pm 929.1$ & $3393.0 \pm 5274.0$ & $149.1 \pm 46.6$ & $564.3 \pm 375.5$ & $433.7 \pm 121.9$ \\
\hline GM-CSF [gggg] & $420.2 \pm 218.5$ & $384.4 \pm 86.8$ & $375.3 \pm 94.4$ & $173.0 \pm 68.1 *$ & $148.6 \pm 47.4$ & $110.1 \pm 75.6 \Delta$ \\
\hline IFN- $\boldsymbol{\gamma}[g]$ & $35.4 \pm 38.6$ & $26.6 \pm 10.5$ & $23.9 \pm 11.3$ & $15.3 \pm 6.8$ & $6.8 \pm 6.4$ & $9.6 \pm 7.0$ \\
\hline KC & $46.4 \pm 62.2$ & $25.3 \pm 9.4$ & $41.1 \pm 28.2$ & $8.8 \pm 1.6$ & $23.1 \pm 11.5$ & $14.9 \pm 2.4$ \\
\hline MCP-1 & $218.2 \pm 132.6$ & $1062.0 \pm 1493.0$ & $286.4 \pm 156.2$ & $75.8 \pm 38.7$ & $190.7 \pm 132.6$ & $95.9 \pm 17.7$ \\
\hline MIP-1a $[g g]$ & $67.2 \pm 47.2$ & $87.8 \pm 38.9$ & $82.5 \pm 54.7$ & $45.1 \pm 15.2$ & $26.3 \pm 8.9$ & $37.1 \pm 11.4$ \\
\hline MIP-1 $\beta$ & $51.9 \pm 36.9$ & $525.1 \pm 909.0$ & $39.4 \pm 13.2$ & $15.2 \pm 4.0$ & $185.8 \pm 335.4$ & $17.4 \pm 15.8$ \\
\hline RANTES & $31.5 \pm 23.1$ & $71.6 \pm 76.2$ & $40.7 \pm 19.4$ & $37.1 \pm 8.5$ & $82.1 \pm 97.6$ & $27.2 \pm 3.9$ \\
\hline TNF- $a$ & $1128.0 \pm 992.2$ & $19244.0 \pm 36869.0$ & $538.0 \pm 207.5$ & $272.8 \pm 81.9$ & $5763.0 \pm 10948.0$ & $363.3 \pm 352.8$ \\
\hline VEGF & $144.6 \pm 32.8(7)$ & $489.7 \pm 420.8(3) * *$ & $132.8 \pm 33.7$ (4) \# & $254.4 \pm 57.0(8)$ & $167.5 \pm 40.9$ (4) \# & $137.3 \pm 22.4(4)$ \\
\hline Leptin & $22290.0 \pm 11260.0(7)$ & $8040.0 \pm 1968.0$ & $25820.0 \pm 18020.0$ & $13680.0 \pm 1899.9(8)$ & $32140.0 \pm 40310.0$ & $39560.0 \pm 44040.0$ \\
\hline PGE Metabolites & $560.1 \pm 676.7(5)$ & $76.7 \pm 13.7(4)$ & $93.9 \pm 51.6(4)$ & $141.3 \pm 122.2$ & $335.0 \pm 158.5$ (3) & $229.0 \pm 202.7(3)$ \\
\hline
\end{tabular}

Concentrations reported as mean \pm standard deviation (SD) and expressed as pg/ml. Except for VEGF, leptin, and PGE metabolites, which were analyzed with separate ELISA kits, all cytokine concentrations were obtained by a multiplex array. *, significantly different from Untreated PPARY-WT, $\mathrm{p}<0.05$; ${ }^{* *}$, significantly different from Untreated PPARY-WT, $p<0.01$; \#, significantly different from DMBA Only-treated PPAR $\gamma$-WT, $p<0.05 ; \Delta$, significantly different from DMBA + ROSI-treated PPAR $\mathrm{W}$-WT, $\mathrm{p}<0.05$. g, genotype different, $\mathrm{p}<0.05$; gg, genotype different, $\mathrm{p}<0.01$; ggg, genotype different, $\mathrm{p}<0.001$; gggg, genotype different, $\mathrm{p}<0.0001$; tt, treatment different $\mathrm{p}<0.01 ; \mathrm{ND}$, not detectable.

With respect to the mouse mammary tumour outcomes observed in these studies, both MG-specific PPARy deficiency and activation produced similar results. Although paradoxical, these comparable outcomes may reflect similar signaling pathways resulting from cofactor mobility. For example, in the PPAR $-\mathrm{MG}$ KO model, coactivators and/or corepressors normally bound by the PPAR $\gamma / \mathrm{RXR} \alpha$ complex may be released to interact with their downstream signaling targets and exert their intended effects similar to when PPAR $\gamma$ is activated. This may partially explain why DMBA Only-treated PPAR $\gamma-\mathrm{MG}$ KOs have better OS compared to DMBA Only-treated PPAR $\gamma$-WTs, but comparable to PPAR $\gamma$-WTs treated with DMBA + ROSI. A similar mechanism has been reported in a PPAR $\beta$ KO mouse model, whereby an antiinflammatory corepressor (Bcl-6) is free to exert its effects in both PPAR $\beta$ deficient and PPAR $\beta$-activated cell contexts [26]. RNAseq and ChIPseq assays evaluating global PPAR $\gamma /$ RXR $\alpha$ interactions with specific cofactors and gene targets would help clarify if this mechanism is involved in the context of breast tumourigenesis, but is beyond the scope of these studies. 
MG-specific expression of PPARy and BRCA1 were confirmed in untreated PPAR $\gamma-\mathrm{WT}$ but abolished in PPAR $\gamma$-MG KO mammary glands. Importantly, ROSI cotreatment increased PPAR $\gamma$ expression in mammaryderived lymphomas and carcinomas from PPAR $\gamma$-WT and PPAR $\gamma-\mathrm{MG}$ KO mice, but only specifically augmented BRCA1 in PPAR $\gamma$-WTs. BRCA1 is a critical tumour suppressor gene that possesses a PPRE within its promoter region [17]. We have previously demonstrated that BRCA1 expression can be upregulated in fat cells via adipocyte-specific PPARY activation [13]. Accordingly, the current study provides similar evidence that BRCA1 is a target of PPAR $\gamma$ in MG cells. This specific interaction may contribute to the improved outcomes observed among DMBA + ROSI-treated PPAR $\gamma$-WT mice, via BRCA1-mediated DNA damage repair and/or blocking aromatase-dependent estrogen production [27].

Cox-2 is a key PG-synthesizing enzyme and a breast cancer prognostic marker of poor outcome [28]. Consequently, Cox-2 protein expression is observed in many epithelial tumours, including breast cancer [29], with increasing levels associated with advanced tumour grade $[30,31]$. ROSI cotreatment repressed Cox-2 in PPAR $\gamma$ WT tumours, but dramatically amplified it in PPAR $\gamma-$ MG KOs. This marked increase in Cox-2 protein levels among DMBA + ROSI-treated PPAR $\gamma-\mathrm{MG}$ KO tumours may partially explain the poor survival and mammary tumour outcomes within this study group. Indeed, Cox2 promotes aromatase transcription [32] and renders cells resistant to apoptosis and even chemotherapy [31]; however, some of these properties may be mediated by PG levels. That we did not observe any significant differences with respect to serum PGE levels in any group provides evidence that other PG products, or perhaps even Cox-2 activity independent of PG production, may be involved in this setting and requires further study.

Although the Cox-2 gene contains a PPRE within its promoter [33,34], PPAR $\gamma$-dependent and PPAR $\gamma$ independent mechanisms both positively and negatively regulate Cox-2 gene transcription depending on celland stimulus-specific contexts [33,35,36,37]. Given Cox2 expression was lower in DMBA + ROSI-treated PPAR $\gamma$-WT tumours suggests MG cell-specific PPAR $\gamma$ activation may play a role in suppressing Cox-2 protein levels, which is similar to our findings with respect to mammary secretory epithelial-PPAR $\gamma$ [14]. On the other hand, DMBA + ROSI-treated PPAR $\gamma$-MG KO tumours showed a dramatic increase in Cox-2 protein levels suggesting that a PPAR $\gamma$-independent process is likely responsible. It has been demonstrated that PPAR $\gamma$ ligands activate Cox-2 transcription via receptor-independent stimulation of the MAPK-NF-kB pathway $[38,39]$. Moreover, PPAR $\gamma$-independent activation of the glucocorticoid receptor by ROSI may also be responsible for increased Cox-2 gene expression [40,41], although this remain to be proven.

The PTEN gene promoter also reportedly contains a PPRE [33,34], and so it was not surprising that PTEN protein levels were markedly reduced among PPAR $\gamma$ MG KO mammary tumours in the DMBA Only group. Interestingly, DMBA + ROSI-treated PPAR $\gamma-\mathrm{WT}$ mice had reduced PTEN expression among mammary tumours than observed in mammary tumours from respective DMBA Only controls. This may be reflective of the decreased mammary tumour progression in DMBA + ROSItreated PPAR $\gamma$-WT mice. Taken together, these data suggest PPAR $\gamma$ is required for normal PTEN expression in malignant mammary tumours, but PTEN is not an early PPAR $\gamma$ downstream signaling target in benign mammary tumours, and may be a fruitful area for research in future studies.

Variable PPARy protein levels were observed among mammary tumours from PPAR $\gamma-W T$ and PPAR $\gamma-\mathrm{MG}$ $\mathrm{KO}$ by Western blot analysis. Among PPAR $\gamma-\mathrm{WT}$ tumours, the variable pattern may reflect alternative pathways acquired during tumourigenic progression of initiated cells, some of which may silence PPAR $\gamma$ expression. There are indeed reports that PPAR levels decline as human breast tissue becomes increasingly malignant [42], which is consistent with our hypothesis of its role as a suppressor of breast tumour progression. Alternatively, the inherent cellular heterogeneity of these mammary tumours, that likely contain differing amounts of PPARy expressing stromal adipocytes, endothelial cells and immune cells, may contribute to the observed variability. Although a possible mosaic expression pattern of the MMTV promoter [43] cannot be discounted, differing percentages of stromal PPAR $\gamma$ expressing cells may also explain the variability of PPAR $\gamma$ expression observed in PPAR $\gamma$-MG KO mammary tumours. This is supported by our IF data showing specificity and extent of PPAR $\gamma$ deletion among mammary epithelial cells of untreated PPAR $\gamma$-MG KO mice. It is also possible that other non-mammary epithelial cell sources of PPAR $\gamma$ signaling may have contributed to the outcomes of these in vivo tumourigenesis studies. We previously showed that mammary adipocyte-specific PPAR $\gamma$ blocks breast tumour progression in part via upregulation of BRCA1 [13]. Interestingly, in the present study, treatment with ROSI caused induction of BRCA1 expression in PPAR $\gamma$ WT, but not PPAR $\gamma$-MG KO mouse mammary tumours. This suggests activation of PPAR $\gamma$ may protect against breast tumour progression only when mammary epithelial-stromal crosstalk contains functional PPAR $\gamma$ signaling in both cell types, and is the focus of additional studies beyond the scope of this work.

Untreated knockout serum contained lower levels of known proinflammatory and chemotactic cytokines, 
including eotaxin, IFN- $\gamma$ and MCP-1 $\alpha$ [44-46], as well as other contextually-dependent proinflammatory signals, such as IL-4 and GM-CSF [45], that could have possibly rendered PPAR $\gamma$-MG KOs less susceptible to breast cancer compared to PPAR $\gamma$-WTs when challenged with DMBA. DMBA + ROSI cotreatment also rescued PPAR $\gamma$-WTs via downregulation of serum VEGF. This may be the result of direct PPAR $\gamma$ activity via a PPRE in the VEGF promoter [47], or indirectly via other PPAR targets such as BRCA1, which can silence VEGF expression and secretion [48], or Cox-2, which can induce VEGF expression [49].

Irrespective of treatment, all PPAR $\gamma$-MG KOs exhibited significantly lower levels of serum IL-4, IL-10, IL13, eotaxin, GM-CSF, IFN- $\gamma$ and MIP- $1 \alpha$ compared to PPAR $\gamma$-WT mice. This is particularly intriguing because these cytokines are commonly produced by macrophages and $T$ lymphocytes $[44,46,50,51]$. Given that this cytokine expression pattern is genotype-specific raises the possibility that PPAR $\gamma$-MG KO mice possess fewer macrophages and $\mathrm{T}$ cells, and thus experience reduced inflammation, compared to PPAR $\gamma$-WTs. This explanation may provide another layer why knockout mice were less susceptible to breast tumourigenesis when challenged with DMBA.

\section{Conclusion}

A summary of MG-specific PPARy loss (Figure 7) illustrates that reduced serum expression of the proinflammatory cytokines, IL-4, eotaxin, GM-CSF, IFN- $\gamma$, and
MIP- $1 \alpha$, rendered PPAR $\gamma$-MG KO mice less susceptible than PPAR $\gamma$-WTs to DMBA-mediated breast tumourigenesis. Here we provide the first in vivo evidence that PPAR $\gamma$ activation in MG cells blocks breast tumour progression in PPAR $\gamma$-WTs by upregulating BRCA1, and downregulating VEGF and Cox-2, expression. Finally, PPAR $\gamma$-independent activation of Cox-2 enhanced breast tumourigenesis in PPAR $\gamma$-MG $\mathrm{KO}$ mice. This study provides insight into the MG cell-specific role of PPAR $\gamma$ during DMBA-mediated breast tumour progression. The results suggest PPAR $\gamma$ signaling in MG cells may be required during early mammary tumourigenesis; however, activation of PPAR $\gamma$ within this cell population is protective against the growth and spread of breast tumours. In sharp contrast, when PPAR $\gamma$ signaling is disrupted in MG cells, the use of activating PPAR $\gamma$ ligands exert a deleterious PPAR $\gamma$-independent effect. Together, these data emphasize the use of PPAR $\gamma$ ligands may be beneficial as novel chemotherapeutic agents for the treatment of a subpopulation of breast cancer patients, and that PPAR $\gamma$ expression may serve as a strong predictive biomarker of patient response.

\section{Materials and methods}

\section{Animals}

All mice were housed and treated in accordance with Canadian Council for Animal Care (CCAC) guidelines under animal protocols approved by the Queen's University Animal Care Committee (UACC) as previously described [14]. Transgenic mice expressing the MMTV-
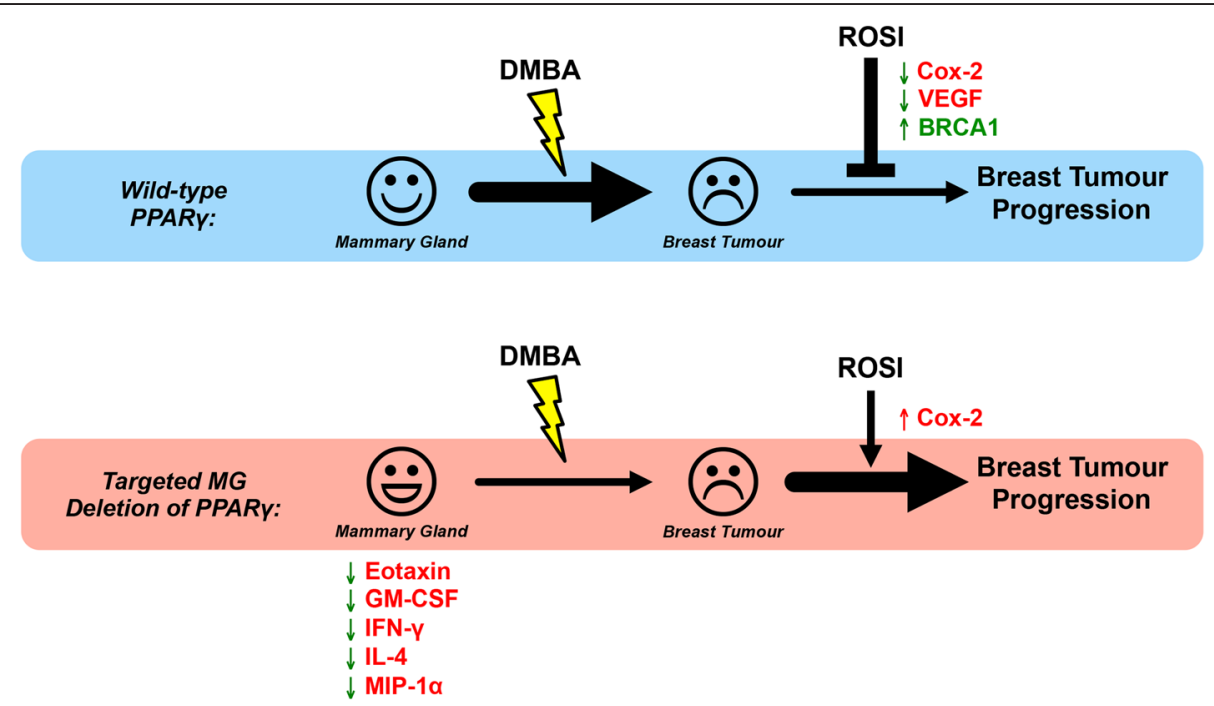

Figure 7 Big picture summary of the effects of MG-specific PPARY loss. PPARY-MG KO mice have decreased serum levels of proinflammatory and chemotactic cytokines (IL-4, eotaxin, GM-CSF, IFN- $\gamma$, and MIP-1a) which may, in part, contribute to their decreased susceptibility to DMBA Only-mediated carcinogenesis compared to PPARY-WTs. Activation of PPARY in MG cells suppresses breast tumourigenesis in PPARY-WT mice by increasing BRCA1 and suppressing VEGF and Cox-2 expression, effectively rescuing PPARY-WT mice from breast tumour progression. In MG cells lacking PPARY expression, DMBA-induced breast tumour progression is enhanced by cotreatment with a PPARY activator, due to PPARY-independent activation of Cox-2. 
LTR-Cre ${ }^{+}$gene were obtained from the NCI-Frederick repository (Frederick, Maryland), and crossed with our previously generated PPAR $\gamma^{(\mathrm{f} / \mathrm{fl})} ; \mathrm{Cre}^{-}(\mathrm{PPAR} \gamma-\mathrm{WT})$ mice [20], to produce PPAR ${ }^{(\mathrm{f} / \mathrm{fl})} ; \mathrm{MMTV}^{\mathrm{L}} \mathrm{LTR}^{-\mathrm{Cre}^{+}}$(PPAR $\gamma$-MG $\mathrm{KO})$ mice. Mouse genotypes were confirmed by PCR analysis (Additional file 2: Figure S2) as before [12].

\section{In vivo breast tumourigenesis}

At age 8-12 weeks, PPAR $\gamma$-WT and PPAR $\gamma-M G$ KO virgin female mice received $1 \mathrm{mg}$ DMBA (Sigma-Aldrich, D3254) by gavage once/week for 6 weeks. At week 7, randomized mice either continued on a regular chow diet (DMBA Only: PPAR $\gamma$-WT, $\mathrm{n}=25$ and PPAR $\gamma$-MG $\mathrm{KO}, \mathrm{n}=39$ ) or received a PPAR $\gamma$ ligand (ROSI; $4 \mathrm{mg} / \mathrm{kg} /$ day)-supplemented chow diet (DMBA + ROSI: PPARyWT, $n=34$ and PPAR $\gamma$-MG KO, $n=17$ ) for the study duration. Mice were monitored for tumourigenic changes for 25 weeks, and tumour samples were harvested as previously described [13]. Non-fasted submandibular blood was obtained pre-, mid- and end-study, and separated to obtain serum samples that were frozen in liquid $\mathrm{N}_{2}$ for future analysis. Pathological staging of tumours was performed in a blinded fashion by collaborating pathologists.

\section{Immunofluorescent (IF) staining}

Formalin-fixed paraffin-embedded untreated mammary glands and mammary tumours from PPAR $\gamma$-WT and PPAR $\gamma$-MG KOs in each treatment group were sectioned and stained as described previously [14]. Sections were stained with primary antibodies for pan-cytokeratin (Dako, M3515; 1:500 dilution) and PPARY (Santa Cruz, sc-7196; 1:500 dilution) or BRCA1 (Santa Cruz, sc-7867; 1:500 dilution). Secondary antibodies used were donkey $\alpha$-rabbit FITC (Santa Cruz, sc-2090; 1:500 dilution) and $\alpha$-mouse Alexa Fluor 594 (Invitrogen, A11005; 1:500 dilution). Slides were coverslipped with mounting media containing DAPI stain (Vectashield). IF staining was visualized with a BX51 System Microscope (Olympus). Images were acquired with QCapture Pro 5.1 software (QImaging) and analyzed with Image-Pro Plus 6.0 software (Media Cybernetics).

\section{Immunoblotting}

Whole-cell extracts were prepared from normal and tumour tissue samples from PPAR $\gamma-W T$ and PPAR $\gamma-$ MG KO mice as previously described [14]. Protein concentrations were quantified using the $D C$ protein assay (BioRad). Proteins were detected with primary antibodies for PPARY (Santa Cruz, sc-7273; 1:500 dilution), $\beta$-actin (Santa Cruz, sc-47778; 1:000 dilution), Cox-2 (Cayman Chemical, \#160126; 1:500 dilution) and PTEN (Cell Signaling, \#9559; 1:1,000 dilution) followed by appropriate HRP-conjugated secondary goat $\alpha$-mouse (Santa
Cruz, sc-2005; 1:10,000 dilution) or goat $\alpha$-rabbit (Santa Cruz, sc-2004; 1:10,000 dilution) antibodies. Protein expression was assessed using ImageJ analysis software (rsbweb.NIH.gov).

\section{Serum assays}

A Bio-Plex Pro Mouse Cytokine 23-plex serum assay kit (BioRad Laboratories) was used to assess cytokine concentrations of IL-1 $\alpha$, IL-1 $\beta$, IL-2, IL-3, IL-4, IL-5, IL-6, IL-9, IL-10, IL-12(p40), IL-12(p70), IL-13, IL-17A, eotaxin, G-CSF, GM-CSF, IFN- $\gamma$, KC, MCP- 1 , MIP- $1 \alpha$, MIP-1 $\beta$, RANTES, and TNF- $\alpha$ as previously described [14]. Clustering and heat map analyses were performed with Cluster 3.0 and TreeView software (Stanford University). Serum VEGF, leptin and prostaglandin E (PGE) metabolites were analyzed using ELISA kits as per manufacturer's (Cayman Chemical) instructions. All cytokine concentrations are reported as the mean \pm standard deviation (SD) $\mathrm{pg} / \mathrm{ml}$.

\section{Statistical analysis}

Differences between genotype and treatment groups were assessed using a Two-Way analysis of variance (ANOVA), followed by a Tukey's post-hoc test for group comparisons. Survival was analyzed using a Log Rank test, and proportions were assessed using Chi-square analysis. GraphPad Prism (Version 6.0) software was used for all analyses. A value of $\mathrm{p}<0.05$ was considered statistically significant.

\section{Additional files}

Additional file 1: Figure S1. PPARY and BRCA1 expression in untreated tissue. Representative immunofluorescence images illustrating expression of cell nuclei (DAPI; in blue), PPARy or BRCA1 (in green) and cytokeratin (CK; in red), with an accompanying composite image, in untreated virgin mammary tissue from PPARY-WT and PPARY-MG KO mice. All photos taken at $\times 600$. Scale bar, $50 \mu \mathrm{m}$.

Additional file 2: Figure S2. Mouse genotyping of PPARY. Mice were genotyped using a standard polymerase chain reaction (PCR) assay as previously described [12]. Representative PCR results obtained using DNA isolated from tails of $(n=3)$ PPARY-WT and PPARY-MG KO mice. Floxed PPARy allele, 285 bp; Cre-mediated recombined null allele, $450 \mathrm{bp}$.

\section{Competing interests}

The authors declare that they have no competing interests.

\section{Authors' contributions}

AA performed animal handling, necropsies and sample collection; performed serum PGE metabolites and 23-plex assays; Western blot assays; data collection and analysis; and drafted the manuscript. JR performed animal handling, necropsies and sample collection; data collection and analysis. MS and SS provided pathological expertise for staging of tumours. RR performed serum VEGF and leptin ELISA assays; NP performed breeding of study animals, dosing and sample collection. MD carried out immunofluorescence assays. CN conceived the study and its design; coordinated and aided with sample collection and data analysis; drafted the manuscript. All authors read and approved the final manuscript. 


\section{Acknowledgements}

This work was made possible through funding to CJN by the Canadian Breast Cancer Foundation (CBCF)-Ontario Region (grant \#369568), Canadian Institutes for Health Research/Canadian Breast Cancer Research Alliance (grant \#84498) as well as Queen's University and Breast Cancer Action Kingston. AA was supported by a CBCF-Ontario Region Doctoral Fellowship, and Terry Fox Foundation Training Program in Transdisciplinary Cancer Research Award. Special thanks to Dr. Wilma Hopman for assistance with statistical methodology. The funding agencies played no part in the study design, data interpretation, preparation or submission of this report.

\section{Author details}

${ }^{1}$ Department of Pathology and Molecular Medicine, Queen's University, Kingston, ON, Canada. 'Division of Cancer Biology and Genetics, Queen's Cancer Research Institute (QCRI), Kingston, ON, Canada. ${ }^{3}$ Department of Biomedical and Molecular Sciences, Queen's University, Kingston, ON, Canada.

\section{Received: 22 December 2014 Accepted: 18 March 2015}

\section{Published online: 15 April 2015}

\section{References}

1. Ferlay J, Soerjomataram I, Ervik M, Dikshit R, Eser S, Mathers C et al. GLOBOCAN 2012 v1.0, Cancer Incidence and Mortality Worldwide: IARC CancerBase No. 11. International Agency for Research on Cancer, Lyon, France. 2013. http://globocan.iarc.fr. Accessed 16/04/2015.

2. Braissant O, Foufelle F, Scotto C, Dauca M, Wahli W. Differential expression of peroxisome proliferator-activated receptors (PPARs): tissue distribution of PPAR-alpha, -beta, and -gamma in the adult rat. Endocrinology. 1996:137(1):354-66. doi:10.1210/endo.137.1.8536636.

3. Jain S, Pulikuri S, Zhu Y, Qi C, Kanwar YS, Yeldandi AV, et al. Differential expression of the peroxisome proliferator-activated receptor gamma (PPARgamma) and its coactivators steroid receptor coactivator-1 and PPAR-binding protein PBP in the brown fat, urinary bladder, colon, and breast of the mouse. Am J Pathol. 1998;153(2):349-54.

4. Mueller E, Sarraf P, Tontonoz P, Evans RM, Martin KJ, Zhang M, et al. Terminal differentiation of human breast cancer through PPAR gamma. Mol Cell. 1998;1(3):465-70.

5. Elstner E, Muller C, Koshizuka K, Williamson EA, Park D, Asou H, et al. Ligands for peroxisome proliferator-activated receptorgamma and retinoic acid receptor inhibit growth and induce apoptosis of human breast cancer cells in vitro and in BNX mice. Proc Natl Acad Sci U S A. 1998;95(15):8806-11.

6. Kotta-Loizou I, Giaginis C, Theocharis S. The role of peroxisome proliferatoractivated receptor-gamma in breast cancer. Anticancer Agents Med Chem. 2012;12(9):1025-44.

7. Campbell MJ, Carlberg C, Koeffler HP. A role for the PPARgamma in cancer therapy. PPAR Res. 2008;2008:314974. doi:10.1155/2008/314974.

8. Straus DS, Glass CK. Anti-inflammatory actions of PPAR ligands: new insights on cellular and molecular mechanisms. Trends Immunol. 2007;28(12):551-8. doi:10.1016/j.it.2007.09.003.

9. Bortolini M, Wright MB, Bopst M, Balas B. Examining the safety of PPAR agonists - current trends and future prospects. Expert Opin Drug Saf. 2013:12(1):65-79. doi:10.1517/14740338.2013.741585.

10. Kim JH, Hubbard NE, Ziboh V, Erickson KL. Conjugated linoleic acid reduction of murine mammary tumor cell growth through 5hydroxyeicosatetraenoic acid. Biochim Biophys Acta. 2005;1687(1-3):103-9. doi:10.1016/j.bbalip.2004.11.007

11. Yin F, Wakino S, Liu Z, Kim S, Hsueh WA, Collins AR, et al. Troglitazone inhibits growth of MCF-7 breast carcinoma cells by targeting G1 cell cycle regulators. Biochem Biophys Res Commun. 2001;286(5):916-22. doi:10.1006/ bbrc.2001.5491.

12. Nicol CJ, Yoon M, Ward JM, Yamashita M, Fukamachi K, Peters JM, et al. PPARgamma influences susceptibility to DMBA-induced mammary, ovarian and skin carcinogenesis. Carcinogenesis. 2004;25(9):1747-55. doi:10.1093/carcin/bgh160.

13. Skelhorne-Gross G, Reid AL, Apostoli AJ, Di Lena MA, Rubino RE, Peterson NT, et al. Stromal adipocyte PPARgamma protects against breast tumorigenesis. Carcinogenesis. 2012;33(7):1412-20. doi:10.1093/carcin/ bgs173.

14. Apostoli AJ, Skelhorne-Gross GE, Rubino RE, Peterson NT, Di Lena MA, Schneider MM, et al. Loss of PPARgamma expression in mammary secretory epithelial cells creates a pro-breast tumorigenic environment. Int J Cancer. 2014;134(5):1055-66. doi:10.1002/ijc.28432.

15. Cui Y, Miyoshi K, Claudio E, Siebenlist UK, Gonzalez FJ, Flaws J, et al. Loss of the peroxisome proliferation-activated receptor gamma (PPARgamma) does not affect mammary development and propensity for tumor formation but leads to reduced fertility. J Biol Chem. 2002;277(20):17830-5. doi:10.1074/jbc.M200186200.

16. Fiennes AG. Growth rate of human tumour xenografts measured in nude mice by in vivo cast modelling. Br J Surg. 1988;75(1):23-4.

17. Pignatelli M, Cocca C, Santos A, Perez-Castillo A. Enhancement of BRCA gene expression by the peroxisome proliferator-activated receptor gamma in the MCF-7 breast cancer cell line. Oncogene. 2003;22(35):5446-50. doi:10.1038/sj.onc.1206824.

18. Saez E, Rosenfeld J, Livolsi A, Olson P, Lombardo E, Nelson M, et al. PPAR gamma signaling exacerbates mammary gland tumor development. Genes Dev. 2004;18(5):528-40. doi:10.1101/gad.1167804.

19. Yin $Y$, Yuan $H$, Zeng $X$, Kopelovich L, Glazer RI. Inhibition of peroxisome proliferator-activated receptor gamma increases estrogen receptordependent tumor specification. Cancer Res. 2009;69(2):687-94. doi:10.1158/0008-5472.CAN-08-2446.

20. Akiyama TE, Sakai S, Lambert G, Nicol CJ, Matsusue K, Pimprale S, et al. Conditional disruption of the peroxisome proliferator-activated receptor gamma gene in mice results in lowered expression of ABCA1, ABCG1, and apoE in macrophages and reduced cholesterol efflux. Mol Cell Biol. 2002;22(8):2607-19.

21. Gavrilova O, Haluzik M, Matsusue K, Cutson JJ, Johnson L, Dietz KR, et al. Liver peroxisome proliferator-activated receptor gamma contributes to hepatic steatosis, triglyceride clearance, and regulation of body fat mass. J Biol Chem. 2003;278(36):34268-76. doi:10.1074/jbc.M300043200.

22. Nicol CJ, Adachi M, Akiyama TE, Gonzalez FJ. PPARgamma in endothelial cells influences high fat diet-induced hypertension. Am J Hypertens. 2005;18(4 Pt 1):549-56. doi:10.1016/j.amjhyper.2004.10.032.

23. Rosak C, Standl E, Reblin T, Stammer H, Seidel DK. Rosiglitazone is effective and well-tolerated in a range of therapeutic regimens during daily practice in patients with type 2 diabetes. Int J Clin Pract. 2006;60(9):1040-7. doi:10.1111/j.1742-1241.2006.01092.x.

24. Dream_Trial_Investigators, Gerstein HC, Yusuf S, Bosch J, Pogue J, Sheridan $P$, et al. Effect of rosiglitazone on the frequency of diabetes in patients with impaired glucose tolerance or impaired fasting glucose: a randomised controlled trial. Lancet. 2006:368(9541):1096-105. doi:10.1016/S01406736(06)69420-8.

25. Welters HJ, El Ouaamari A, Kawamori D, Meyer J, Hu J, Smith DM, et al, Rosiglitazone promotes PPARgamma-dependent and -independent alterations in gene expression in mouse islets. Endocrinology. 2012;153(10):4593-9. doi:10.1210/en.2012-1243.

26. Takata Y, Liu J, Yin F, Collins AR, Lyon CJ, Lee CH, et al. PPARdelta-mediated antiinflammatory mechanisms inhibit angiotensin I-accelerated atherosclerosis. Proc Natl Acad Sci U S A. 2008;105(11):4277-82. doi:10.1073/pnas.0708647105.

27. Ghosh S, Lu Y, Katz A, Hu Y, Li R. Tumor suppressor BRCA1 inhibits a breast cancer-associated promoter of the aromatase gene (CYP19) in human adipose stromal cells. Am J Physiol Endocrinol Metab. 2007;292(1):E246-52. doi:10.1152/ajpendo.00242.2006.

28. Hoellen F, Kelling K, Dittmer C, Diedrich K, Friedrich M, Thill M. Impact of cyclooxygenase-2 in breast cancer. Anticancer Res. 2011;31(12):4359-67.

29. Denkert C, Winzer KJ, Muller BM, Weichert W, Pest S, Kobel M, et al. Elevated expression of cyclooxygenase-2 is a negative prognostic factor for disease free survival and overall survival in patients with breast carcinoma. Cancer. 2003:97(12):2978-87. doi:10.1002/cncr.11437.

30. Half E, Tang XM, Gwyn K, Sahin A, Wathen K, Sinicrope FA. Cyclooxygenase-2 expression in human breast cancers and adjacent ductal carcinoma in situ. Cancer Res. 2002;62(6):1676-81.

31. Thill M, Fischer D, Becker S, Cordes T, Dittmer C, Diedrich $K$, et al. Prostaglandin metabolizing enzymes in correlation with vitamin D receptor in benign and malignant breast cell lines. Anticancer Res. 2009;29(9):3619-25.

32. Diaz-Cruz ES, Shapiro CL, Brueggemeier RW. Cyclooxygenase inhibitors suppress aromatase expression and activity in breast cancer cells. J Clin Endocrinol Metab. 2005;90(5):2563-70. doi:10.1210/jc.2004-2029.

33. Hazra S, Dubinett SM. Ciglitazone mediates COX-2 dependent suppression of PGE2 in human non-small cell lung cancer cells. Prostaglandins Leukot Essent Fatty Acids. 2007;77(1):51-8. doi:10.1016/j.plefa.2007.05.006. 
34. Patel L, Pass I, Coxon P, Downes CP, Smith SA, Macphee $\mathrm{CH}$. Tumor suppressor and anti-inflammatory actions of PPARgamma agonists are mediated via upregulation of PTEN. Curr Biol. 2001;11(10):764-8.

35. Meade EA, Mclntyre TM, Zimmerman GA, Prescott SM. Peroxisome proliferators enhance cyclooxygenase-2 expression in epithelial cells. J Biol Chem. 1999;274(12):8328-34

36. Patel KM, Wright KL, Whittaker P, Chakravarty P, Watson ML, Ward SG. Differential modulation of COX-2 expression in A549 airway epithelial cells by structurally distinct PPAR(gamma) agonists: evidence for disparate functional effects which are independent of NF-(kappa)B and PPAR(gamma). Cell Signal. 2005;17(9):1098-110. doi:10.1016/j.cellsig.2004.12.002.

37. Bren-Mattison Y, Meyer AM, Van Putten V, Li H, Kuhn K, Stearman R, et al. Antitumorigenic effects of peroxisome proliferator-activated receptorgamma in non-small-cell lung cancer cells are mediated by suppression of cyclooxygenase-2 via inhibition of nuclear factor-kappaB. Mol Pharmacol. 2008;73(3):709-17. doi:10.1124/mol.107.042002.

38. Ackerman $\mathrm{WE}$, Zhang $\mathrm{XL}$, Rovin $\mathrm{BH}$, Kniss DA. Modulation of cytokineinduced cyclooxygenase 2 expression by PPARG ligands through NFkappaB signal disruption in human WISH and amnion cells. Biol Reprod. 2005;73(3):527-35. doi:10.1095/biolreprod.104.039032.

39. Straus DS, Pascual G, Li M, Welch JS, Ricote $\mathrm{M}$, Hsiang $\mathrm{CH}_{\text {, et al. }}$ 15-deoxy-delta 12,14-prostaglandin $J 2$ inhibits multiple steps in the NF-kappa B signaling pathway. Proc Natl Acad Sci U S A. 2000;97(9):4844-9.

40. Pujols L, Benitez P, Alobid I, Martinez-Anton A, Roca-Ferrer J, Mullol J, et al. Glucocorticoid therapy increases COX-2 gene expression in nasal polyps in vivo. Eur Respir J. 2009;33(3):502-8. doi:10.1183/09031936.00017408.

41. Matthews L, Berry A, Tersigni M, D'Acquisto F, lanaro A, Ray D. Thiazolidinediones are partial agonists for the glucocorticoid receptor. Endocrinology. 2009;150(1):75-86. doi:10.1210/en.2008-0196.

42. Wang C, Pattabiraman N, Zhou JN, Fu M, Sakamaki T, Albanese C, et al. Cyclin D1 repression of peroxisome proliferator-activated receptor gamma expression and transactivation. Mol Cell Biol. 2003;23(17):6159-73.

43. Ahmed F, Wyckoff J, Lin EY, Wang W, Wang Y, Hennighausen L, et al. GFP expression in the mammary gland for imaging of mammary tumor cells in transgenic mice. Cancer Res. 2002;62(24):7166-9.

44. Nolen BM, Lokshin AE. Targeting CCL11 in the treatment of ovarian cancer Expert Opin Ther Targets. 2010;14(2):157-67. doi:10.1517/14728220903512983.

45. Kleemann R, Zadelaar S, Kooistra T. Cytokines and atherosclerosis: a comprehensive review of studies in mice. Cardiovasc Res. 2008;79(3):360-76. doi:10.1093/cvr/cvn120.

46. Maurer M, von Stebut E. Macrophage inflammatory protein-1. Int J Biochem Cell Biol. 2004;36(10):1882-6. doi:10.1016/j.biocel.2003.10.019.

47. Peeters LL, Vigne JL, Tee MK, Zhao D, Waite LL, Taylor RN. PPAR gamma represses VEGF expression in human endometrial cells: implications for uterine angiogenesis. Angiogenesis. 2005;8(4):373-9. doi:10.1007/s10456-005-9027-4.

48. Kawai H, Li H, Chun P, Avraham S, Avraham HK. Direct interaction between BRCA1 and the estrogen receptor regulates vascular endothelial growth factor (VEGF) transcription and secretion in breast cancer cells. Oncogene. 2002;21(50):7730-9. doi:10.1038/sj.onc.1205971.

49. Singh-Ranger G, Salhab M, Mokbel K. The role of cyclooxygenase-2 in breast cancer: review. Breast Cancer Res Treat. 2008;109(2):189-98. doi:10.1007/ s10549-007-9641-5.

50. Lee S, Margolin K. Cytokines in cancer immunotherapy. Cancers. 2011;3(4):3856-93. doi:10.3390/cancers3043856.

51. McKenzie AN, Culpepper JA, De Waal MR, Briere F, Punnonen J, Aversa G, et al. Interleukin 13, a T-cell-derived cytokine that regulates human monocyte and B-cell function. Proc Natl Acad Sci U S A. 1993;90(8):3735-9.

\section{Submit your next manuscript to BioMed Central and take full advantage of:}

- Convenient online submission

- Thorough peer review

- No space constraints or color figure charges

- Immediate publication on acceptance

- Inclusion in PubMed, CAS, Scopus and Google Scholar

- Research which is freely available for redistribution

Submit your manuscript at www.biomedcentral.com/submit 